Original article

Section: Food Technology

\title{
Pear Juice Clarification Using Polygalacturonase from Beauveria bassiana: Effects on Rheological, Antioxidant and Quality Properties
}

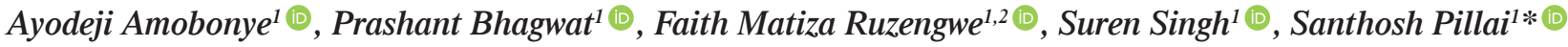 \\ ${ }^{1}$ Department of Biotechnology and Food Science, Faculty of Applied Sciences, Durban University of Technology, \\ PO Box 1334, Durban, 4000, South Africa \\ ${ }^{2}$ Department of Food Science and Technology, Chinhoyi University of Technology, P. Bag 7724, Chinhoyi, Zimbabwe
}

Key words: antioxidant, Beauveria bassiana, juice clarification, enzyme, pear juice, polygalacturonase, rheology

\begin{abstract}
Although pear is one of the most preferred fruits globally due to its high nutrient content, its juice products have not received equal consumer acceptability due to their undesirable haziness and turbidity. However, enzymatic treatment of juice has been noted to improve the overall acceptability of juices better than traditional decantation, filtration, and heating methods, which are either expensive or detrimental to the product quality. In this study, pear juice was effectively clarified using partially purified polygalacturonase from an entomopathogenic fungal endophyte Beauveria bassiana SAN01. The optimization of the juice clarification process led to $137 \%$ improvement in clarification compared to control, under optimal conditions of $39.37 \mathrm{U} / \mathrm{mL}$ enzyme load, $36.87^{\circ} \mathrm{C}$ temperature and $2.75 \mathrm{~h}$ treatment time. Results also showed that the polygalacturonase treatment resulted in a significant decrease in viscosity and an increase in the pseudoplasticity of the pear juice as the rheological data of the juice was observed to fit adequately into the power law model $\left(\mathrm{R}^{2}>0.9\right)$. Furthermore, the enzyme-assisted juice clarification was found to reduce browning index $(-14.34 \%)$ and turbidity (-19.72\%) while increasing the reducing sugar content $(9.55 \%)$. Unlike some conventional juice treatments, the polygalacturonase treatment preserved the antioxidant potential and the total phenolic contents of the pear juice as no significant changes were observed after the treatment. This study thus demonstrates the efficacy of a fungal polygalacturonase in improving pear juice quality as well as the potential applicability of B. bassiana enzymes in the food industry.
\end{abstract}

\section{INTRODUCTION}

Enzymes have continued to gain prominence in food processing over traditional chemical- and mechanical-based methods, as they are eco-friendly and have been shown to increase food nutritional value, with lesser energy input requirement [Kumar et al., 2016]. Various carbohydrases have since been produced commercially for their applications in fruit juice processing, as the potential of novel enzyme sources in enhancing customer desirability is continually being investigated. These biocatalysts are used to improve the clarity of fruit products such as juices, as consumer preference for well-clarified fruit juices devoid of opalescence is gaining more popularity [Sharma et al., 2017]. Furthermore, clarification of juice is critical as haze- and sediment-forming substances diminish fruit juice quality during storage [Dıblan \& Özkan, 2021]. Pectinolytic enzymes, including pectinesterases, polygalacturonases, pectin lyases, and protopectinases, have been the most exploited enzymes in this regard [Ramadan, 2019]. This is because the turbidity of fruit products is mainly caused by pectin, the primary plant polysaccharide in fruit products; hence, the pectinolytic enzymes hydrolyze pectic substances, promoting the flocculation of suspended particles and enhancing clarification [Karmakar \& De, 2019].

However, the presence of other polysaccharides including cellulose, hemicellulose, starch as well as other compounds, such as lignin, oxidized phenolics, polyphenols, proteins, tannins, and metals, have also been implicated in the turbidity and cloudiness of different juices [Narnoliya et al., 2020; Ogando et al., 2019]. Hence, eliminating these components from fruit juices before packaging or serving to consumers is critical [Narnoliya et al., 2020]. Additionally, the action of pectinase on fruit juices releases sugars that enhance the sweetness of the products, minimizing the addition of extra sweeteners. However, besides improving the physical attributes of fruit juices, the maintenance or improvement of their nutritional content is just as important during juice processing. The major nutritional benefit of fruit juices is attributed to their vitamins and antioxidants; however, different processing methods have shown detrimental effects on these constituents, particularly a reduction in their contents. For example, heat processing has been shown to reduce the vitamin

\footnotetext{
* Corresponding Author:

E-mail: santhoshk@dut.ac.za (S. Pillai)
} 
contents of juice [Ordóñez-Santos \& Martínez-Girón, 2020], while UV-radiation to decrease the antioxidant properties [Islam et al., 2016]. However, despite different studies on the enzymatic clarification of fruit juices, the effects of these treatments on their nutritional contents have not been well demonstrated.

Pear is considered one of the most widely consumed fruits worldwide, and its popularity has been attributed to its high fiber, minerals, vitamins, and antioxidants [Salta et al., 2010]. However, despite these remarkable qualities, especially the high nutrient content, it has been observed that pear juices are not as desirable as other fruit juices, especially apple and orange juices. This relatively low consumer acceptance of pear juice has been partly attributed to its haziness and insipid flavor, hence, the need for a more effective processing technology to meet consumer's preferences [Xie et al., 2007].

Beauveria bassiana, though more widely known as an entomopathogenic fungal endophyte [Thaochan et al., 2021], has also been shown to secrete different industrially important metabolites and enzymes including amylase, cellulase, chitinase, lipase and protease [Amobonye et al., 2020]. The potential of the fungus to produce these biological macromolecules and its established safety for human use have thus prompted the application of many of its enzymes in chemical biotransformation [Shankar \& Laxman, 2015]. We have previously demonstrated the potentials of partially purified $B$. bassiana endoglucanase and xylanase cocktail in biomass saccharification [Amobonye et al., 2021b] as well as the potential of purified xylanase in wastepaper deinking [Amobonye et al., 2021a]. Hence, this study investigated the enzymatic clarification of pear juice using partially purified polygalacturonase from B. bassiana SAN01. In this regard, the quality of pear juice was enhanced by statistically optimizing the enzymatic treatment using the central composite design of response surface methodology. Subsequently, the effects of the treatment on the rheological properties, color, total soluble solids, turbidity, and reducing sugar levels of the juice were evaluated. Furthermore, the total phenolic and flavonoid contents and antioxidant activities of the juice were selected as indicators of its functional quality after treatment. To the best of our knowledge, this is the first scientific attempt at clarifying pear juice after the extraction process using a microbial enzyme, as well as optimizing the process via a statistical approach.

\section{MATERIALS AND METHODS}

\section{Chemicals and reagents}

The wheat bran used in the study was obtained locally in Durban, South Africa. Activated charcoal, Folin-Ciocalteu reagent, gallic acid and 3,5-dinitrosalicylic acid (DNS) were purchased from Sigma-Aldrich (Saint Louis, MO, USA). All other chemicals and reagents used were of analytical grade and were obtained from validated suppliers.

\section{Microorganism and enzyme production}

The polygalacturonase used for the clarification of pear juice was produced from B. bassiana SAN01, which was isolated locally in its endophytic state from onion leaves [Amobonye et al., 2021b]. The enzyme production was carried out under submerged fermentation conditions in a shaking incubator $(120 \mathrm{rpm})$ using $1 \mathrm{~mL}$ of inoculum $\left(1 \times 10^{7}\right.$ spores $\left./ \mathrm{mL}\right)$. The fermentation conditions include an initial media $\mathrm{pH}$ of 6.0 , incubation temperature of $30.42^{\circ} \mathrm{C}$ and wheat bran concentration of $47.2 \mathrm{~g} / \mathrm{L}$. The polygalacturonase activity was measured using $1 \%$ orange peel pectin, while the reducing sugars released were determined by the DNS method according to Bailey et al. [1992]. One unit (U) of polygalacturonase activity is defined as the amount of enzyme liberating $1 \mu \mathrm{mol}$ of galacturonic acid per min, under standard assay conditions $\left(40^{\circ} \mathrm{C}, 50 \mathrm{mM}\right.$ phosphate buffer, $\left.\mathrm{pH} 5.5\right)$.

\section{Partial purification and decolorization of the enzyme}

The crude enzyme was partially purified by ammonium sulphate precipitation $(60 \%)$ for $24 \mathrm{~h}$ at $4^{\circ} \mathrm{C}$ and centrifuged at $10,000 \times g$ for $20 \mathrm{~min}$ at $4^{\circ} \mathrm{C}$ using a refrigerated centrifuge (Eppendorf 5810R, Hamburg, Germany). The precipitate was reconstituted in citrate buffer $(50 \mathrm{mM}, \mathrm{pH} 5.5)$ and desalted by dialysis. Subsequently, the precipitated protein was decolorized using activated charcoal to obtain a clear enzyme. In this regard, $1 \%$ activated charcoal was added to the enzyme solution and incubated at $4^{\circ} \mathrm{C}$ for 30 min with gentle stirring. The mixture was then centrifuged at $5,000 \times g$ for $10 \mathrm{~min}$ to recover a clear supernatant [Kareem et al., 2011]. Finally, the enzyme was concentrated by ultrafiltration using $10 \mathrm{kDa}$ membrane centrifugal filter (Millipore Corp., Billerica, MA, USA) and passed through sterile syringe filters $(0.2 \mathrm{~mm})$ (Millipore Corp.) to remove microbial contaminants and other suspended solids.

\section{Juice processing}

Pears (Forelle varieties) weighing $\sim 170 \mathrm{~g}$ were purchased from a local shop in Durban, South Africa. The fruits were washed thoroughly with distilled water, deseeded manually, chopped, and extracted using a juicer. The extract was rapidly strained through a stainless-steel sieve ( $3 \mathrm{~mm}$ pore diameter) for the separation of the suspended matter. Subsequently, the extract was vacuum filtered using Whatman ${ }^{\circledR}$ Grade 3 filter paper, transferred to clean Schott bottles and pasteurized in a water bath (Memmert WB 22, Memmert GmbH + Co. $\mathrm{KG}$, Schwabach, Germany) at $95^{\circ} \mathrm{C}$ for $1 \mathrm{~min}$ [Petruzzi et al., 2017].

\section{Enzyme-assisted pear juice clarification}

The Design Expert 11.0 (Stat-Ease, Minneapolis, USA) software was employed for the statistical optimization of the enzyme-assisted clarification of pear juice [Amobonye et al., 2021b]. For each treatment, $50 \mathrm{~mL}$ of pear juice was subjected to different enzyme treatment conditions (Table 1). The three process parameters selected for the optimization of enzyme treatments by central composite design (CCD) as well as their ranges were identified from previous studies [Saxena et al., 2014] and also based on preliminary experiments in our laboratory. These include the enzyme load, incubation time and temperature. Incubation was performed in a circulating water bath (IncuMax WB10C Water Bath, Amerex Instruments, Inc., Concord, CA, United States) with continuous agitation $(50 \mathrm{rpm})$ while keeping the juice at its natural $\mathrm{pH}$ $(\mathrm{pH}$ 3.9). The partially purified polygalacturonase $(40 \mathrm{U} / \mathrm{mL})$ 
TABLE 1. Coded and uncoded variables of the response surface design for the clarification of pear juice.

\begin{tabular}{l|c|c|c|c|c|c}
\hline \multirow{2}{*}{$\begin{array}{l}\text { Independent } \\
\text { variables }\end{array}$} & \multirow{2}{*}{ Units } & \multicolumn{5}{|c}{ Levels } \\
\cline { 3 - 8 } & & -1.68 & -1 & 0 & +1 & +1.68 \\
\hline Enzyme load (A) & $\mathrm{U} / \mathrm{mL}$ & 20 & 24.22 & 30 & 35.77 & 40 \\
Temperature (B) & ${ }^{\circ} \mathrm{C}$ & 30 & 34.23 & 40 & 45.78 & 50 \\
Time (C) & $\mathrm{h}$ & 1 & 1.42 & 2 & 2.58 & 3 \\
\hline
\end{tabular}

was used in the optimization process and the enzyme treatment was terminated by heating the juice at $90^{\circ} \mathrm{C}$ for $1 \mathrm{~min}$. The experimental design in the coded levels of process variables is summarized in Table 1. The optimization design was made of 15 combinations including 5 replicates of the center point and juice clarity was determined as the response.

\section{Rheological properties of pear juice}

Rheological properties of the juice samples were evaluated according to Domingues et al. [2011], using a rheometer (MCR102, Anton Paar GmbH, Graz, Austria), fitted with a parallel plate (50 $\mathrm{mm}$ diameter, $1.5 \mathrm{~mm}$ gap). The rheometer was equipped with a Peltier system (TEZ-15P-C) with a temperature accuracy of $0.01{ }^{\circ} \mathrm{C}$. For the steady flow studies, $2 \mathrm{~mL}$ of juice samples were placed between the plates. The shear stress $(\mathrm{Pa})$ and viscosity were observed linearly increasing from $1 \mathrm{~s}^{-1}$ shear rate to $300 \mathrm{~s}^{-1}$; the data points were collected and analyzed using US200 Universal Software (Paar Physica, Anton Paar GmbH). The shear rate range used in this study is in line with many food processing applications such as pumping, grinding, in-pipe flow, mixing and stirring [Deshmukh et al., 2015].

\section{Evaluation of fruit juice characteristics}

Juice clarity

The change in percent transmittance $(\Delta \% \mathrm{~T})$ was considered a measure of the juice clarity [Zhao et al., 2019]. Initially, the absorbance of the juice samples was recorded at $660 \mathrm{~nm}$ with a UV-VIS spectrophotometer (Model UV-1201, Shimadzu Corp., Kyoto, Japan) with distilled water and heat-inactivated enzyme serving as the blank and the control respectively. Subsequently, the change in percent transmittance $(\Delta \% \mathrm{~T})$ was calculated according to the formula given below.

$$
\text { Juice clarity }(\Delta \% \mathrm{~T})=\frac{\left(\% \mathrm{~T}_{\mathrm{s}}-\% \mathrm{~T}_{\mathrm{b}}\right) \times 100}{\% \mathrm{~T}_{\mathrm{c}}-\% \mathrm{~T}_{\mathrm{b}}}
$$

where: $\% \mathrm{~T}_{\mathrm{s}}$ - percent transmittance of test sample; $\% \mathrm{~T}_{\mathrm{b}}-$ percent transmittance of blank; $\% \mathrm{~T}_{\mathrm{c}}$ - percent transmittance of control.

\section{Browning index and turbidity determination}

To determine the browning index, $5 \mathrm{~mL}$ of juice sample was mixed with $5 \mathrm{~mL}$ of $95 \%$ ethanol and centrifuged at $4,000 \times g$ for $10 \mathrm{~min}$. The supernatant obtained was passed through a $0.45 \mu \mathrm{m}$ membrane filter, and the absorbance was measured at $420 \mathrm{~nm}$ [Uçan et al., 2016]. The turbidity of the juice was determined using a Turbidometer (Oxoid, Basingstoke, UK) and reported as nephelometric turbidity units (NTU) using hexamethylenetetramine solution as a standard [Pradhan et al., 2020].

\section{Reducing sugars, total dissolved solids and titratable acidity}

Reducing sugars released after the enzymatic treatment of pear juice were determined using the DNS method [Bailey et al., 1992]. Total soluble solids were measured using a digital refractometer with automatic temperature compensation (Atago Co., Ltd, Tokyo, Japan) and expressed as ${ }^{\circ}$ Brix (\%). The $\mathrm{pH}$ of the juice was measured using a benchtop $\mathrm{pH}$-meter (Hanna Instruments, Woonsocket, RI, USA), while the titratable acidity was estimated by titrating $10 \mathrm{~mL}$ of diluted juice (1:10; juice: distilled water) with $0.1 \mathrm{~N} \mathrm{NaOH}$ solution, using phenolphthalein as an indicator, and the acidity value was expressed in citric acid (0.0064 acid factor) equivalents [Santana et al., 2021].

\section{Color measurement}

The color parameters (CIE $\left.L^{*} a^{*} b^{*}\right)$ of the raw and treated juice samples were measured using a ColorFlex EZ Spectrophotometer (Hunter Associates Laboratory Inc., Reston, VA, USA), where $L$ value indicates lightness while $a^{*}$ denotes the red/green value $((+)$ : red; $(-)$ : green $)$ and $b^{*}$ the yellow/ blue value $((+)$ : yellow; $(-)$ : blue $)$. Furthermore, the chroma $\left(C^{*}\right)$ of the samples was calculated according to the formula (2) [Uçan et al., 2016].

$$
C^{*}=\sqrt{\left(a^{*}\right)^{2}+\left(b^{*}\right)^{2}}
$$

\section{Analysis of antioxidant activities and phenolic contents} DPPH radical scavenging activity

Reaction mixtures containing the sample $(100 \mathrm{~mL})$ and $\mathrm{DPPH}^{\cdot}(3.9 \mathrm{~mL}, 50 \mu \mathrm{M})$ in methanol were incubated in a water bath at $37^{\circ} \mathrm{C}$ for $30 \mathrm{~min}$. The absorbance was measured at $517 \mathrm{~nm}$ using a Thermo Scientific GENESYS UVVis Spectrophotometer (Thermo Scientific, Waltham, MA, USA) and the DPPH ${ }^{\bullet}$ scavenging activity was calculated by the equation (3):

$$
\begin{gathered}
\text { DPPH radical scavenging activity }(\%)= \\
=\left[\left(\mathrm{Abs}_{0}-\mathrm{Abs}_{1}\right) / \mathrm{Abs}_{0}\right] \times 100
\end{gathered}
$$

where: $\mathrm{Abs}_{0}$ and $\mathrm{Abs}_{1}$ are the absorbance values of control (without juice) and test samples, respectively [Wang et al., 2019].

\section{Total phenolic content}

The total phenolic content of juices was analyzed according to a modified method using Folin-Ciocalteu reagent. Each sample $(0.1 \mathrm{~mL})$ was mixed with $0.75 \mathrm{~mL}$ of diluted Folin-Ciocalteu reagent $(10 \% \mathrm{v} / \mathrm{v})$ and incubated for $5 \mathrm{~min}$ at room temperature and $0.75 \mathrm{~mL}$ of $2 \%$ sodium carbonate solution was added. After incubation for $15 \mathrm{~min}$ at room temperature, the absorbance of the solution was read at $750 \mathrm{~nm}$. Gallic acid was used as the standard, and total phenolic content was expressed as mg gallic acid equivalents (GAE) per L of juice [Romero-González et al., 2020].

\section{Total flavonoid content}

The total flavonoid content (TFC) of juices was estimated spectrophotometrically based on the aluminium chloride 
colorimetric method [Cheng et al., 2016]. Juice samples $(0.5 \mathrm{~mL})$ were added to $4.5 \mathrm{~mL}$ of an aluminium chloride reagent consisting of $10 \%$ aluminium chloride $(0.1 \mathrm{~mL}), 1 \mathrm{M}$ potassium acetate $(0.1 \mathrm{~mL}), 95 \%$ ethanol $(1.5 \mathrm{~mL})$ and distilled water $(2.8 \mathrm{~mL})$. The absorbance of the reaction mixture was measured at $415 \mathrm{~nm}$ after incubation at room temperature for $30 \mathrm{~min}$. The TFC in each juice sample was calculated based on a standard calibration curve of quercetin and expressed as mg quercetin equivalents (QE) per $\mathrm{L}$ of juice. The aluminium chloride reagent mixture alone, without the addition of the sample, was used as a blank.

\section{Ferric reducing antioxidant power (FRAP)}

The FRAP assay was performed using a modified Wang et al. [2019] method. Briefly, a FRAP reagent was prepared from $300 \mathrm{mM}$ acetate and glacial acetic acid buffer ( $\mathrm{pH} 3.6$ ), $20 \mathrm{mM}$ ferric chloride and $10 \mathrm{mM}$ 4,6-tripryridyl-s-triazine (TPTZ) made up in $40 \mathrm{mM} \mathrm{HCl}$. All three solutions were mixed in the ratio 10:1:1, v/v/v. The FRAP assay was performed by incubating $1 \mathrm{~mL}$ of $\mathrm{dH}_{2} \mathrm{O}, 25 \mu \mathrm{L}$ of juice and $1 \mathrm{~mL}$ of the FRAP reagent at $37^{\circ} \mathrm{C}$. The absorbance readings at time zero and after $40 \mathrm{~min}$ were recorded at $593 \mathrm{~nm}$ [Benzie \& Strain, 1996]. Ferrous sulphate was used as the standard, and the FRAP was expressed in $\mu \mathrm{mol}$ of $\mathrm{Fe}$ (II) per $\mathrm{mL}$ of juice.

\section{Statistical analysis}

All the data presented are the mean \pm standard deviation of triplicate values. The variation between groups was evaluated using the Duncan test and one-way analysis of variance (ANOVA) of the IBM SPSS v26 software package (IBM Corp., Armonk, NY, USA). A significance level of 5\% was used in all the analyses.

\section{RESULTS AND DISCUSSION}

\section{Optimization of enzyme-assisted pear juice treatment}

The efficacy of the B. bassiana SAN01 polygalacturonase in the clarification of pear juice was evaluated by response surface methodology (RSM) using a CCD design while measuring the juice clarity under different conditions as the response (Table 2). In the design of 15 experimental runs, pear juice clarity varied considerably from $25.46 \%$ and $100 \%$ with changing process conditions (Table 2). These results showed that the pear juice clarity was significantly improved by optimizing the enzyme load, incubation temperature and incubation period. In addition, close agreements were observed between all the experimental and predicted values in this study. It is posited that the polygalacturonase hydrolyzed the pectin into different monomers and oligomers, creating protein-sugar complexes which aggregated into larger particles and settled, resulting in improved clarity. Data from this study is corroborated by similar findings from previous investigations [Ahmed \& Sohail, 2020; Sorrivas et al., 2006].

The reliability of the model was confirmed from the F-value (41.06) and $p$-values as observed from the ANOVA (Table 3). The model, as well as some of the terms (A, B, C and AC), were found to be significant, judging from their $p$-values. However, exceptions were noticed in $\mathrm{AB}$ and $\mathrm{BC}$ with $p$-value greater than 0.05 , which suggests that the interactive effects
TABLE 2. Central composite design (CCD) optimization of pear juice clarification and the response of the dependent variables.

\begin{tabular}{c|c|c|c|c|c}
\hline \multirow{2}{*}{} & \multicolumn{3}{|c|}{ Level } & \multicolumn{2}{c}{ Clarity (\%)* } \\
\cline { 2 - 6 } & $\mathrm{A}^{* *}$ & $\mathrm{~B}$ & $\mathrm{C}$ & Actual & Predicted \\
\hline 1 & +1.68 & 0 & 0 & 74.87 & 77.72 \\
2 & 0 & -1.68 & 0 & 38.48 & 41.28 \\
3 & 0 & +1.68 & 0 & 61.95 & 64.75 \\
4 & 0 & 0 & -1.68 & 32.51 & 36.41 \\
5 & 0 & 0 & +1.68 & 65.72 & 69.62 \\
6 & +1 & -1 & +1 & 100.00 & 99.46 \\
7 & 0 & 0 & 0 & 56.12 & 53.02 \\
8 & -1.68 & 0 & 0 & 25.46 & 28.31 \\
9 & 0 & 0 & 0 & 58.06 & 53.02 \\
10 & -1 & -1 & -1 & 39.22 & 38.68 \\
11 & 0 & 0 & 0 & 51.19 & 53.02 \\
12 & +1 & +1 & -1 & 36.79 & 36.25 \\
13 & 0 & 0 & 0 & 59.15 & 53.02 \\
14 & -1 & +1 & +1 & 38.22 & 37.68 \\
15 & 0 & 0 & 0 & 57.53 & 53.02 \\
\hline
\end{tabular}

*Average of triplicate determinations. **Details of codes A, B \& C are given in Table 1.

of the variables are not consequential. The model showed a high $\mathrm{R}^{2}$ value of 0.9685 , which demonstrates that the model can account for $\sim 97 \%$ of the total variation and represent significant correlations among the selected variables.

The interactions between the selected factors affecting the optimized clarification of pear juice were also represented in contour and response surface plots (Figure 1). The interaction between $\mathrm{AB}$ was moderately significant ( $p$-value 0.0726 ), with increasing the dose of enzyme, a simultaneous increase in juice clarification was observed where $20 \mathrm{U} / \mathrm{mL}$ showed $28 \%$, while $40 \mathrm{U} / \mathrm{mL}$ showed $78 \%$ juice clarification, keeping time at zero level $(2 \mathrm{~h})$. While with increasing temperature, the juice clarification moderately increased, showing $41 \%$ clarification at $30^{\circ} \mathrm{C}$ and $65 \%$ at $50^{\circ} \mathrm{C}$, suggesting the inefficiency of the enzyme to work both at low and high temperature regimes (Figure 1a). The interaction between AC was most significant ( $p$-value $<0.0001)$, where both incubation time and enzyme load were found to interact considerably (Figure 1b). However, at an extreme lower enzyme dosage of $20 \mathrm{U} / \mathrm{mL}$ and incubation time of $1 \mathrm{~h}$, the juice clarification was not effective. In contrast, a sharp increase in juice clarification was observed (39-100\%) with a steady rise in both the factors, comprising enzyme load $(24-36 \mathrm{U} / \mathrm{mL})$ and incubation time (1.4-2.6 h), while keeping the temperature at $34^{\circ} \mathrm{C}$. The interaction among $\mathrm{BC}$ was found to be statistically insignificant ( $p$-value 0.8473 ), suggesting little interactions between incubation time and incubation temperature (Figure 1c), which is mainly because of the level of enzyme dosage which was studied at zero level $(30 \mathrm{U} / \mathrm{mL})$. It further 

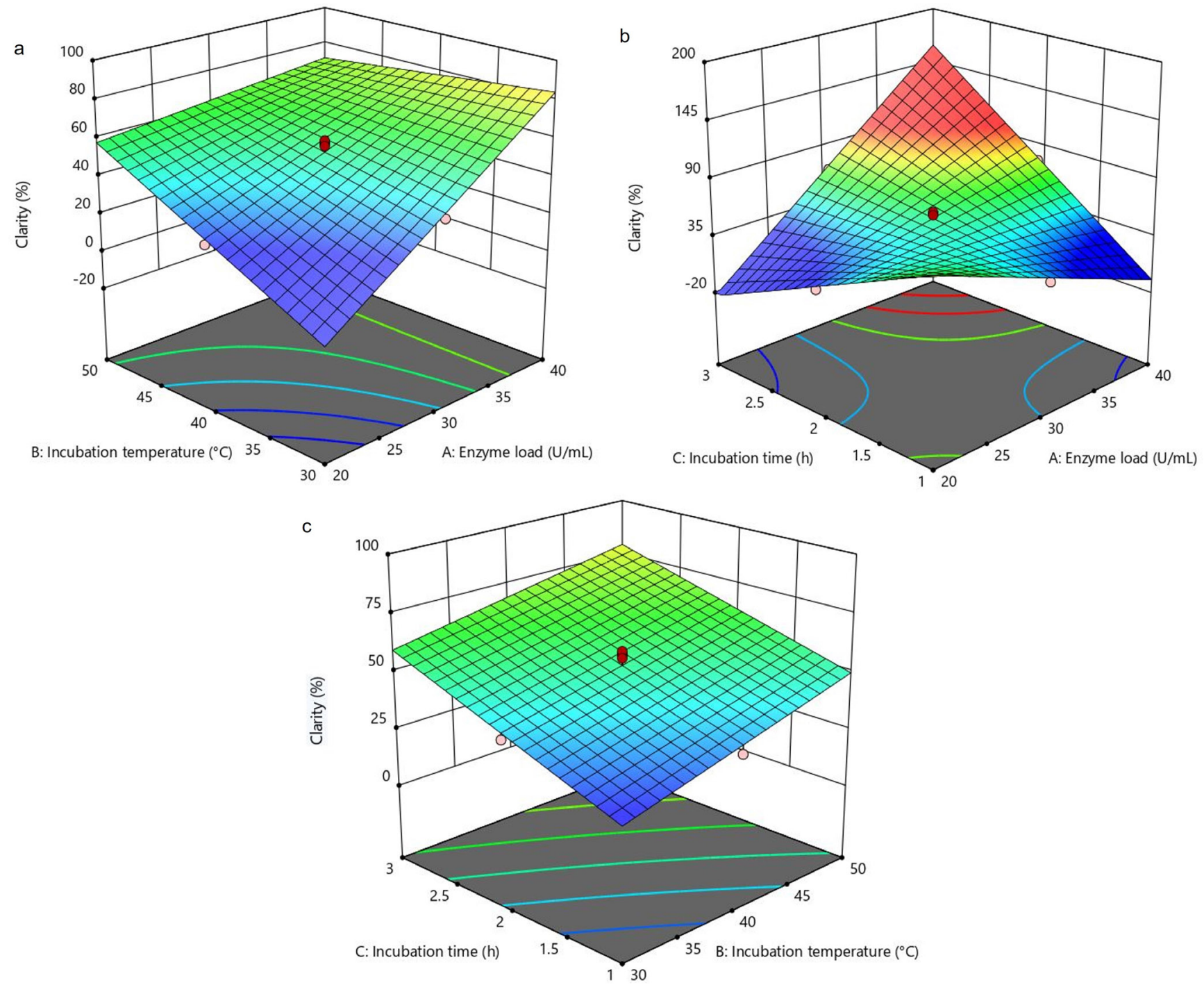

FIGURE 1. Response surface plots showing the interactions between the variables for enzymatic clarification of pear juice: (a) 3D plots of enzyme load - incubation temperature interaction; (b) 3D plots of enzyme load - incubation time interaction; (c) 3D plots of incubation time - incubation temperature interaction.

substantiates enzyme dose as the most critical factor, corroborated by its lowest $p$-value $(<0.0001)$ (Table 3$)$.

\section{Validation of the experimental model}

The adequacy of the model was further validated by conducting the enzyme treatment using derived optimal conditions. The conditions predicted for optimum pear juice clarification were enzyme load $(39.37 \mathrm{U} / \mathrm{mL})$, incubation temperature $\left(36.87^{\circ} \mathrm{C}\right)$ and time $(2 \mathrm{~h} 45 \mathrm{~min})$ with a desirability of 0.927 . As suggested by the model, the predicted value of maximum clarification, $140.65 \%$, was in close agreement with the experimental value of $137 \pm 7.1 \%$. Hence, the proximity between the predicted and experimental values points to the adequate prediction of the generated model. Thus, by applying the CCD designs, a 1.37-fold increase in clarity relative to the control was recorded.

\section{Effect of enzyme treatment on pear juice rheology}

The relationship between the shear stress and shear rate of the raw and enzyme-treated pear juice is shown
TABLE 3. Results of the analysis of variance (ANOVA) of quadratic models for pear juice clarification.

\begin{tabular}{lcccccc}
\hline Source & $\begin{array}{c}\text { Sum } \\
\text { of Squares }\end{array}$ & df & $\begin{array}{c}\text { Mean } \\
\text { Square }\end{array}$ & F-value & $p$-Value* \\
\hline Model & 4926.40 & 6 & 821.07 & 41.06 & $<0.0001$ \\
$\mathrm{~A}^{* *}$ & 1220.67 & 1 & 1220.67 & 61.05 & $<0.0001$ \\
$\mathrm{~B}$ & 275.42 & 1 & 275.42 & 13.77 & 0.0059 \\
$\mathrm{C}$ & 551.45 & 1 & 551.45 & 27.58 & 0.0008 \\
$\mathrm{AB}$ & 85.41 & 1 & 85.41 & 4.27 & 0.0726 \\
$\mathrm{AC}$ & 1250.65 & 1 & 1250.65 & 62.54 & $<0.0001$ \\
$\mathrm{BC}$ & 0.7909 & 1 & 0.7909 & 0.0396 & 0.8473 \\
Residual & 121.15 & 8 & 20.00 & & \\
Lack of Fit & 38.82 & 4 & 30.29 & 3.12 & 0.1481 \\
\hline
\end{tabular}

$\mathrm{R}^{2}=0.9685$, adjusted $\mathrm{R}^{2}=0.945$, predicted $\mathrm{R}^{2}=0.9061$, adequate precision $(\mathrm{AP})=23.291$.

*Significant at $p<0.05$. **Details of codes A, B \& C are given in Table 1. 
in Figure 2a. The rheograms of the raw and enzyme-clarified juice showed a monotonical increase in the shear stress with increasing shear rate. Subsequently, the Ostwald-de Waele model or power law equation was used to describe the relationships between the two variables as the recorded rate of increase of the shear stress was not directly linear to the shear rate increase [Sanchez et al., 2009; Tavares et al., 2007]:

$$
\sigma=k \times \gamma^{n}
$$

where: $\sigma$ is the shear stress $(\mathrm{Pa}), k$ is the consistency coefficient $\left(\operatorname{Pa} \times \mathrm{s}^{\mathrm{n}}\right), \gamma$ is the shear rate $\left(\mathrm{s}^{-1}\right)$ and $n$ is the flow behavior index (-).

It was observed that flow behaviors of the raw and enzyme-treated juice samples fitted well within the power law model as shown by the $\mathrm{R}^{2}>0.9$ (Table 4). Flow behavior index $n<1$ shows pseudoplasticity whilst $n=1$ shows Newtonian flow behavior. In this study, an increase in pseudoplasticity/shear thinning was observed after enzymatic treatment of the juice. In addition, the consistency coefficient, $k$, showed that the polygalacturonase treatment of pear juice decreased viscosity at any given shear rate (Table 4).

Similarly, a decrease in the viscosity values was observed in both samples with the increase in the shear rate (Figure 2b), and the treated juice was observed to be less viscous than
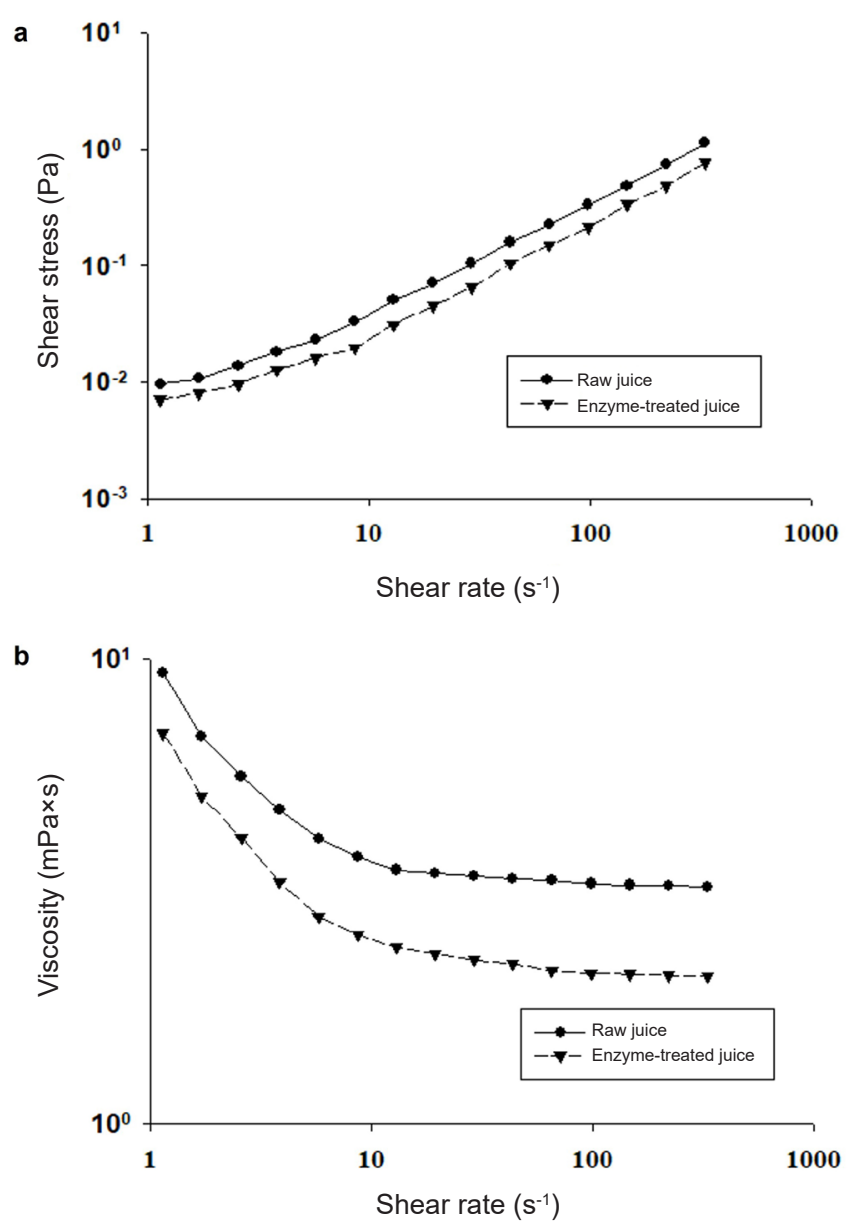

FIGURE 2. Effect of enzyme treatment on the (a) shear stress and (b) viscosity profile as a function of shear rate of pear juice.
TABLE 4. Power-law model coefficients of raw and enzyme-treated pear juice.

\begin{tabular}{l|c|c|c}
\hline & $k\left(\mathrm{~Pa} \times \mathrm{s}^{\mathrm{n}}\right)$ & $n$ & $\mathrm{R}^{2}$ \\
\hline Raw juice & $0.0061 \pm 0.0002$ & $0.89 \pm 0.03$ & 0.9977 \\
Enzyme-treated juice & $0.0047 \pm 0.0001$ & $0.87 \pm 0.03$ & 0.9962 \\
\hline
\end{tabular}

Results expressed as mean \pm standard deviation; $k$ : consistency coefficient, $n$ : flow behavior index, $\mathrm{R}^{2}$ : coefficient of determination.

the raw juice. Thus, it could be inferred that the observed decrease in the viscosity after enzymatic treatment is due to the hydrolytic action of the enzyme on the pectic materials present in the juice. This hydrolytic action of the enzyme results in reduced water holding capacity of the juice and subsequent release of free water into the system, reducing juice viscosity [Sharma et al., 2017]. Similar flow behaviors have also been highlighted in previous clarification studies of various juices including apricot, banana, and sapodilla [Sharma et al., 2017].

In practical terms, a reduction in the viscosity of fruit juice is considered vital as it prevents problems such as fouling of membrane surfaces encountered during the subsequent filtration process which often reduce juice quality and increase production cost. Furthermore, the reduction in viscosity and cluster formation resulting from the enzymatic clarification of juices further facilitates separation through centrifugation and filtration. Ultimately, these result in the final juice product exhibiting greater clarity, more concentrated flavor and color [Abdullah et al., 2007; Sharma et al., 2017]. In addition, many consumers have also shown preferences for juice products with relatively lower viscosity [Salehi, 2020].

\section{Effect of enzyme treatment on pear juice quality}

The color of food products is a major determining factor in customer preference. It has been observed that many consumers prefer brighter or lighter juices, hence, the color and the clarity of beverages are usually considered as standard quality indicators [Gonzalez Viejo et al., 2019]. Browning, both enzymatic and non-enzymatic, has been noted for its detrimental effects on the nutritional and sensory appeal of fruit products. For example, in pear juice, the color has been noted to be one of the reasons for its non-preference by consumers [Xie et al., 2007]. Furthermore, dark-colored fruit products are usually associated with deterioration, hence, a reduction in the dark color is desirable [Beveridge \& Wrolstad, 1997; Singh et al., 2021]. In this study, a reduction in browning $(\sim 14 \%)$ of pear juice was observed after the treatment with the fungal polygalacturonase (Table 5), indicating its effectives in improving the pear juice quality. The beneficial effect of polygalacturonase treatment is also demonstrated by the $\sim 10 \%$ increase in reducing sugar content after processing (Table 5). This expected increase in reducing sugar content, which has also been observed in previous studies on juice clarification [Adedeji \& Ezekiel, 2020; Yang et al., 2019], is a result of the hydrolytic action of the glycosyl hydrolase on the pectin present in the raw juice. Furthermore, the increment in reducing sugar content is expected to enhance the sweetness and flavor of the juice products, thus, limiting the need for extra sweeteners during further processing. 
TABLE 5. Effect of enzyme treatment on pear juice properties.

\begin{tabular}{l|c|c|c}
\hline & \multicolumn{1}{c|}{$\begin{array}{c}\text { Raw } \\
\text { juice }\end{array}$} & $\begin{array}{c}\text { Enzyme- } \\
\text {-treated juice }\end{array}$ & $\begin{array}{c}\text { Percent } \\
\text { change }\end{array}$ \\
\hline Browning index & $0.26 \pm 0.01$ & $0.22 \pm 0.01$ & $-14.34^{*}$ \\
Color $L^{*}$ & $14.23 \pm 0.34$ & $17.53 \pm 0.41$ & $23.19^{*}$ \\
$\quad a^{*}$ & $-1.23 \pm 0.04$ & $-0.83 \pm 0.04$ & $32.52^{*}$ \\
$\qquad b^{*}$ & $3.71 \pm 0.11$ & $6.27 \pm 0.26$ & $69.00^{*}$ \\
$\quad C^{*}$ & $3.91 \pm 0.14$ & $6.33 \pm 0.31$ & $61.89^{*}$ \\
$\mathrm{pH}$ & $3.93 \pm 0.04$ & $3.79 \pm 0.03$ & -3.56 \\
$\begin{array}{l}\text { Reducing sugar content } \\
\text { (mg/mL) }\end{array}$ & $75.5 \pm 2.3$ & $82.6 \pm 2.7$ & $9.55^{*}$ \\
$\begin{array}{l}\text { Titratable acidity } \\
\text { (g/100 mL) }\end{array}$ & $0.28 \pm 0.01$ & $0.27 \pm 0.01$ & -3.57 \\
$\begin{array}{l}\text { Total dissolved solids } \\
\text { (Brix \%) }\end{array}$ & $8.90 \pm 0.1$ & $9.2 \pm 0.2$ & 3.37 \\
$\begin{array}{l}\text { Turbidity } \\
\text { (NTU) }\end{array}$ & $1411 \pm 74$ & $1132 \pm 35$ & $-19.72^{*}$ \\
\hline
\end{tabular}

Results expressed as mean \pm standard deviation $(n=3)$. *Significant at $p<0.05$.

It is also probable that the increased reducing sugar content observed in this study could be inhibitory to polyphenol oxidase and consequently resulted in reducing browning. Reducing sugars have been previously noted in this regard to inhibit the activity of polyphenol oxidase [Moon et al., 2020; Nicoli et al., 1991], an enzyme that has been implicated in enzymatic browning [Jiang et al., 2016].

A significant improvement in the clarity of the juice was also inferred from the color change observed subsequent to the enzyme treatment as demonstrated by the $\sim 23 \%$ increase in $L^{*}$ value (Table 5). The increase in $L^{*}$ value was also observed in a recent study on the application of pectinase in extracting juices from pears [Gani et al., 2021]. Furthermore, there was an increase in the redness and yellowness of the enzyme-treated juice compared to the control, as deduced from the positive changes in the $a^{*}$ and $b^{*}$ values. Likewise, the increase in the color intensity and the brightness of the processed juice was also shown by the significant increase in the chroma value (61.89\%) (Table 5).

Turbidity has been shown as a quality discriminant in fruit juice processing affecting food product stability [Salehi, 2020; Sharma et al., 2017]. Turbidity in fruit juices results from unhydrolyzed complex carbohydrates, hence the hydrolysis of pectin has been identified as a significant step in this regard [Sorrivas et al., 2006]. The efficacy of the B. bassiana polygalacturonase in the juice clarification process was highlighted by a $\sim 20 \%$ reduction in its turbidity (Table 5 ). A similar trend in turbidity was also observed in the clarification of apple, grape and peach juices using polygalacturonase from Coriolus versicolor and Penicillium notatum [Amin et al., 2017]. The reduction in turbidity and viscosity observed in this study after enzymatic treatment is also complemented by the observed increase in reducing sugar content. This could be comparable with a finding from Yang et al. [2019] where a linear relationship existed between complex sugars (substrates) clearance, and the reducing sugars (products) released.
TABLE 6. Effect of enzyme treatment on pear juice antioxidant properties.

\begin{tabular}{lccc}
\hline & Raw juice & $\begin{array}{c}\text { Enzyme- } \\
\text {-treated juice }\end{array}$ & $\begin{array}{c}\text { Percent } \\
\text { change }\end{array}$ \\
\hline $\begin{array}{l}\text { DPPH• scavenging activity } \\
(\%)\end{array}$ & $66.0 \pm 2.2$ & $68.2 \pm 3.0$ & 3.23 \\
$\begin{array}{l}\text { Total phenolic content } \\
(\mathrm{mg} \mathrm{GAE} / \mathrm{L})\end{array}$ & $318.0 \pm 12.3$ & $313.0 \pm 7.3$ & -1.57 \\
$\begin{array}{l}\text { Total flavonoid content } \\
(\mathrm{mg} \mathrm{QE} / \mathrm{L})\end{array}$ & $118.6 \pm 3.4$ & $136.8 \pm 4.7$ & $15.35^{*}$ \\
$\begin{array}{l}\text { FRAP } \\
(\mu \mathrm{mol} \text { of Fe }(\mathrm{II}) / \mathrm{mL})\end{array}$ & $133.1 \pm 5.0$ & $132.7 \pm 6.7$ & -0.34 \\
\hline
\end{tabular}

Results expressed as mean \pm standard deviation $(n=3)$; GAE: gallic acid equivalents, QE: quercetin equivalents, FRAP: ferric reducing antioxidant power. *Significant at $p<0.05$.

The $\mathrm{pH}$, titratable acidity, and total dissolved solids (Brix \%) have been identified as important factors in the quality control of fruit juices, especially regarding storage stability [Adedeji \& Ezekiel, 2020]. Minor fluctuations were observed between the $\mathrm{pH}$ of the control and the treated juice as only a $3.56 \%$ change was recorded (Table 5). Similar trends were observed for titratable acidity and total dissolved solids in previous enzymatic treatments of banana and strawberry juices, where the $\mathrm{pH}$, titratable acidity and total dissolved solids were barely affected [Barman et al., 2015; Sandri \& Silveira, 2018]. The observed reduction in the $\mathrm{pH}$ and increase in titratable acidity is believed to be due to the release of galacturonic acid which is the hydrolytic product of pectin while the rise in Brix (\%) could be due to the enzyme-facilitated degradation of the complex carbohydrate polymers in the juices [Bora et al., 2017; Kyamuhangire et al., 2002].

\section{Effect of $B$. bassiana polygalacturonase on antioxidant properties and phenolic contents}

The increase in juice consumption has been ascribed to the reported health benefits of their antioxidants [Ern et al., 2016]; hence, it is crucial to determine the effect of the enzymatic treatment on the antioxidant properties of fruit juices. Studies have shown the detrimental effects of various treatment processes, such as thermal, mechanical and irradiation, on the desirable antioxidant benefits of fruits and their products [Al-juhaimi et al., 2018]. Though polygalacturonase treatment has been shown in a few studies to have negative effects on the DPPH radical scavenging activity of fruit juices, a slight increase in the scavenging activity (of 3.32\%) was observed for pear juice after the polygalacturonase treatment (Table 6). Hence, it is hypothesized that the polygalacturonase enzyme was involved in the hydrolysis of the different linkages and complexes made between pear juice antioxidants and its pectin [Ribas-Agustí et al., 2018].

Phenolics including flavonoids contribute the most to the antioxidant activities of fruits and their products. In this study, the total phenolic contents were not significantly affected after enzyme clarification; however, there was a significant increase $(15.25 \%)$ in the total flavonoid content (Table 6). Pear juices have been shown to be very rich in phenolic compounds, including arbutin, chlorogenic acid, epicatechin, quercetin 3-glucoside, quercetin 3-galactoside and quercetin 3-rutinoside [Schieber et al., 2001]. It is posited that 
the hydrolytic action of the enzyme could release these compounds bound to the cell wall as well as cleave the internal glycosidic bonds of flavonoids into their aglycone moieties, thus, causing a significant increase in total flavonoids, and consequently an increase in the antioxidant activity, as shown previously by Mandalari et al. [2006]. Furthermore, it has also been noted that the enhancement of total antioxidative activity might be due to an increase in flavonoid aglycones [Gu et al., 2019]. The FRAP assay is regarded as one of the best tests for determining the antioxidant capabilities of fruit juices [Sethi et al., 2020]. The antioxidant activities, as measured by the FRAP method, were shown to be preserved in pear juice following $B$. bassiana polygalacturonase treatment as no significant change was observed. This recorded preservation of FRAP in processed juice relative to the untreated juice could be corroborated with previous studies such as in the enzyme-assisted processing of Indian plum juice [Koley et al., 2011].

\section{CONCLUSIONS}

Despite the popularity of the pear fruit, very little focus has been placed on its juice as a commercial product unlike other popular fruits, such as apples, oranges and pineapples. As earlier highlighted, this might partly be due to the undesirable cloudiness post-extraction. According to available literature, there are no research focused on the clarification of extracted pear juice, and particularly, no attempt has been made using microbial enzymes in that process. Thus, this study effectively utilized RSM to establish the optimum parameters for pear juice clarification using $B$. bassiana polygalacturonase. The optimal clarification conditions were validated using the conditions derived from the CCD model. The analysis of the quality characteristics and some biochemical properties has revealed that the polygalacturonase treatment had no detrimental effect on the most-desired physical and antioxidant properties of the juice. It was further observed that the enzyme-assisted treatment significantly enhanced many of the characteristics of the product, which are in line with customer and industrial preferences. Hence, results from this study have demonstrated, for the first time, the practical application of a novel fungal enzyme in improving some organoleptic properties of pear juice, especially the visual appeal. Like most fungi, $B$. bassiana has been shown to be acidophilic, thus, it is most probable that the polygalacturonase from this study will perform optimally at the acidic $\mathrm{pH}$ range, which is most suitable for its application in the juice and wine industries. However, further investigation into the enzyme's biochemical characteristics, its stability, and the effects of different immobilization methods on its activity will enhance its probability of being considered a commercial enzyme. Thus, in addition to the already established safety of the fungus and its products, findings from this study further underscore its applicability in many industrial processes, particularly in juice processing. Therefore, $B$. bassiana could be considered an important candidate for food processing enzymes, in addition to its well-known use in the agricultural industry.

\section{RESEARCH FUNDING}

This work was supported by the National Research Foundation of South Africa under grant numbers [UID 105447 and UID 114227].

\section{CONFLICT OF INTERESTS}

The authors declare that they have no known competing financial interests or personal relationships that could have influenced the work reported in this paper.

\section{ORCID IDs}

A. Ayodeji https://orcid.org/0000-0002-3220-5858

P. Bhagwat https://orcid.org/0000-0001-5790-7824

S. Pillai https://orcid.org/0000-0003-3474-1555

F.M. Ruzengwe https://orcid.org/0000-0001-8589-7475

S. Singh https://orcid.org/0000-0003-1064-6297

\section{REFERENCES}

1. Abdullah, A.L., Sulaiman, N., Aroua, M., Noor, M.M.M. (2007). Response surface optimization of conditions for clarification of carambola fruit juice using a commercial enzyme. Journal of Food Engineering, 81(1), 65-71.

https://doi.org/10.1016/j.jfoodeng.2006.10.013

2. Adedeji, O.E., Ezekiel, O.O. (2020). Chemical composition and physicochemical properties of mango juice extracted using polygalacturonase produced by Aspergillus awamori CICC 2040 on pretreated orange peel. LWT - Food Science and Technology, 132, art. no. 109891.

https://doi.org/10.1016/j.lwt.2020.109891

3. Ahmed, A., Sohail, M. (2020). Characterization of pectinase from Geotrichum candidum AA15 and its potential application in orange juice clarification. Journal of King Saud University-Science, 32(1), 955-961.

https://doi.org/10.1016/j.jksus.2019.07.002

4. Al-juhaimi, F., Ghafoor, K., Özcan, M.M., Jahurul, M., Babiker, E.E., Jinap, S., Sahena, F., Sharifudin, M., Zaidul, I. (2018). Effect of various food processing and handling methods on preservation of natural antioxidants in fruits and vegetables. Journal of Food Science and Technology, 55(10), 3872-3880. https://doi.org/10.1007/s13197-018-3370-0

5. Amin, F., Bhatti, H.N., Bilal, M., Asgher, M. (2017). Multiple parameter optimizations for enhanced biosynthesis of exo-polygalacturonase enzyme and its application in fruit juice clarification. International Journal of Food Engineering, 13(2), art. no. 20160256 .

https://doi.org/10.1515/ijfe-2016-0256

6. Amobonye, A., Bhagwat, P., Pandey, A., Singh, S., Pillai, S. (2020). Biotechnological potential of Beauveria bassiana as a source of novel biocatalysts and metabolites. Critical Reviews in Biotechnology, 40(7), 1019-1034. https://doi.org/10.1080/07388551.2020.1805403

7. Amobonye, A., Bhagwat, P., Singh, S., Pillai, S. (2021a). Beauveria bassiana xylanase: characterization and wastepaper deinking 
potential of a novel glycosyl hydrolase from an endophytic fungal entomopathogen. Journal of Fungi, 7(8), art. no. 668. https://doi.org/10.3390/jof7080668

8. Amobonye, A., Bhagwat, P., Singh, S., Pillai, S. (2021b). Enhanced xylanase and endoglucanase production from Beauveria bassiana SAN01, an entomopathogenic fungal endophyte. Fungal Biology, 125(1), 39-48.

https://doi.org/10.1016/j.funbio.2020.10.003

9. Bailey, M.J., Biely, P., Poutanen, K. (1992). Interlaboratory testing of methods for assay of xylanase activity. Journal of Biotechnology, 23(3), 257-270.

https://doi.org/10.1016/0168-1656(92)90074-J

10. Barman, S., Sit, N., Badwaik, L.S., Deka, S.C. (2015). Pectinase production by Aspergillus niger using banana (Musa balbisiana) peel as substrate and its effect on clarification of banana juice. Journal of Food Science and Technology, 52 (6), 3579-3589. https://doi.org/10.1007/s13197-014-1413-

11. Benzie, I.F., Strain, J.J. (1996). The ferric reducing ability of plasma (FRAP) as a measure of "antioxidant power": the FRAP assay. Analytical Biochemistry, 239(1), 70-76. https://doi.org/10.1006/abio.1996.0292

12. Beveridge, T., Wrolstad, R.E. (1997). Haze and cloud in apple juices. Critical Reviews in Food Science and Nutrition, 37(1), 75-91. https://doi.org/10.1080/10408399709527768

13. Bora, S.J., Handique, J., Sit, N. (2017). Effect of ultrasound and enzymatic pre-treatment on yield and properties of banana juice. Ultrasonics Sonochemistry, 37, 445-451.

https://doi.org/10.1016/j.ultsonch.2017.01.039

14. Cheng, S.H., Khoo, H., Ismail, A., Abdul-Hamid, A., Barakatun-Nisak, M. (2016). Influence of extraction solvents on Cosmos caudatus leaf antioxidant properties. Iranian Journal of Science and Technology, Transactions A: Science, 40(1), 51-58.

https://doi.org/10.1007/s40995-016-0007-x

15. Deshmukh, P.S., Manjunatha, S.S., Raju, P.S. (2015). Rheological behaviour of enzyme clarified sapota (Achras sapota $\mathrm{L}$ ) juice at different concentration and temperatures. Journal of Food Science and Technology, 52(4), 1896-1910.

https://doi.org/10.1007/s13197-013-1222-5

16. Diblan, S., Özkan, M. (2021). Effects of various clarification treatments on anthocyanins, color, phenolics and antioxidant activity of red grape juice. Food Chemistry, 352, art. no. 129321. https://doi.org/10.1016/j.foodchem.2021.129321

17. Domingues, R.C., Junior, S.B., Silva, R.B., Madrona, G.S., Cardoso, V.L., Reis, M.H. (2011). Evaluation of enzymatic pretreatment of passion fruit juice. Chemical Engineering Transactions, 24, 517-522.

18. Ern, K., Aron, H.A.H., Eng, C. (2016). Comparison of total phenolic contents (tpc) and antioxidant activities of fresh fruit juices, commercial 100\% fruit juices and fruit drinks Sains Malaysiana, 45(9), 1319-1327.

19. Gani, G., Naik, H., Jan, N., Bashir, O., Hussain, S.Z., Rather, A., Reshi, M., Amin, T. (2021). Physicochemical and antioxidant properties of pear juice prepared through pectinase enzyme-assisted extraction from William Bartlett variety. Journal of Food Measurement and Characterization, 15(1), 743-757. https://doi.org/10.1007/s11694-020-00676-x

20. Gonzalez Viejo, C., Torrico, D.D., Dunshea, F.R., Fuentes, S. (2019). Emerging technologies based on artificial intelligence to assess the quality and consumer preference of beverages. Beverages, 5(4), art. no. 62.

https://doi.org/10.3390/beverages5040062

21. Gu, Q., Duan, G., Yu, X. (2019). Bioconversion of flavonoid glycosides from Hippophae rhamnoides leaves into flavonoid aglycones by Eurotium amstelodami. Microorganisms, 7(5), art. no. 122 .

https://doi.org/10.3390/microorganisms7050122

22. Islam, M.S., Patras, A., Pokharel, B., Wu, Y., Vergne, M.J., Shade, L., Xiao, H., Sasges, M. (2016). UV-C irradiation as an alternative disinfection technique: Study of its effect on polyphenols and antioxidant activity of apple juice. Innovative Food Science and Emerging Technologies, 34, 344-351.

https://doi.org/10.1016/j.ifset.2016.02.009

23. Jiang, G.H., Kim, Y.M., Nam, S.H., Yim, S.H., Eun, J.B. (2016). Enzymatic browning inhibition and antioxidant activity of pear juice from a new cultivar of asian pear (Pyrus pyrifolia Nakai cv. Sinhwa) with different concentrations of ascorbic acid. Food Science and Biotechnology, 25(1), 153-158.

https://doi.org/10.1007/s10068-016-0023-9

24. Kareem, S., Akpan, I., Popoola, T., Sanni, L. (2011). Activated charcoal - a potential material in glucoamylase recovery. Enzyme Research, 2011, art. no. 483943.

https://doi.org/10.4061/2011/483943

25. Karmakar, S., De, S. (2019). Pectin removal and clarification of juices. Chapter 5, In: Ch.M. Galanakis (Ed.), Separation of Functional Molecules in Food by Membrane Technology, Elsevier, Academic Press, pp. 155-194.

https://doi.org/10.1016/B978-0-12-815056-6.00005-X

26. Koley, T.K., Walia, S., Nath, P., Awasthi, O., Kaur, C. (2011). Nutraceutical composition of Zizyphus mauritiana Lamk (Indian ber): effect of enzyme-assisted processing. International Journal of Food Sciences and Nutrition, 62(3), 276-279. https://doi.org/10.3109/09637486.2010.526930

27. Kumar, K., Arumugam, N., Permaul, K., Singh, S. (2016). Thermostable enzymes and their industrial applications. Chapter 5, In: P. Shukla (Ed.), Microbial Biotechnology Interdisciplinary Approach, $1^{\text {st }}$ ed., CRC Press, Boca Raton, USA, pp. 115-162. https://doi.org/10.1201/9781315367880

28. Kyamuhangire, W., Myhre, H., Sørensen, H.T., Pehrson, R. (2002). Yield, characteristics and composition of banana juice extracted by the enzymatic and mechanical methods. Journal of the Science of Food and Agriculture, 82(4), 478-482. https://doi.org/10.1002/jsfa.1052

29. Mandalari, G., Bennett, R.N., Kirby, A.R., Lo Curto, R.B., Bisignano, G., Waldron, K.W., Faulds, C.B. (2006). Enzymatic hydrolysis of flavonoids and pectic oligosaccharides from bergamot (Citrus bergamia Risso) peel. Journal of Agricultural and Food Chemistry, 54(21), 8307-8313. https://doi.org/10.1021/jf0615799

30. Moon, K.M., Kwon, E.B., Lee, B., Kim, C.Y. (2020). Recent trends in controlling the enzymatic browning of fruit and vegetable products. Molecules, 25(12), art. no. 2754. https://doi.org/10.3390/molecules25122754

31. Narnoliya, L.K., Jadaun, J.S., Chownk, M., Singh, S.P. (2020). Enzymatic systems for the development of juice clarification strategies. Chapter 18, In: S.P. Singh, A. Pandey, R.R. Singhania, Ch. Larroche, Z. Li (Eds.), Biomass, Biofuels, Biochemi- 
cals - Advances in Enzyme Catalysis and Technologies, Elsevier, pp. 397-412.

https://doi.org/10.1016/B978-0-12-819820-9.00018-1

32. Nicoli, M.C., Elizalde, B.E., Pitotti, A., Lerici, C.R. (1991). Effect of sugars and maillard reaction products on polyphenol oxidase and peroxidase activity in food. Journal of Food Biochemistry, 15(3), 169-184.

https://doi.org/10.1111/j.1745-4514.1991.tb00153.x

33. Ogando, F.I.B., de Aguiar, C.L., Viotto, J.V.N., Heredia, F.J., Hernanz, D. (2019). Removal of phenolic, turbidity and color in sugarcane juice by electrocoagulation as a sulfur-free process. Food Research International, 122, 643-652.

https://doi.org/10.1016/j.foodres.2019.01.039

34. Ordóñez-Santos, L.E., Martínez-Girón, J. (2020). Thermal degradation kinetics of carotenoids, vitamin $\mathrm{C}$ and provitamin A in tree tomato juice. International Journal of Food Science and Technology, 55(1), 201-210.

https://doi.org/10.1111/ijfs.14263

35. Petruzzi, L., Campaniello, D., Speranza, B., Corbo, M.R., Sinigaglia, M., Bevilacqua, A. (2017). Thermal treatments for fruit and vegetable juices and beverages: A literature overview. Comprehensive Reviews in Food Science and Food Safety, 16(4), 668-691.

https://doi.org/10.1111/1541-4337.12270

36. Pradhan, D., Abdullah, S., Pradhan, R.C. (2020). Optimization of pectinase assisted extraction of chironji (Buchanania lanzan) fruit juice using response surface methodology and artificial neural network. International Journal of Fruit Science, 20(Suppl. 2), S318-S336.

https://doi.org/10.1080/15538362.2020.1734895

37. Ramadan, M.F. (2019). Enzymes in fruit juice processing. Chapter 4, In: M. Kuddus (Ed.), Enzymes in Food Biotechnology - Production, Applications, and Future Prospects, Elsevier, Academic Press, pp. 45-59.

https://doi.org/10.1016/B978-0-12-813280-7.00004-9

38. Salta, J., Martins, A., Santos, R.G., Neng, N.R., Nogueira, J.M., Justino, J., Rauter, A.P. (2010). Phenolic composition and antioxidant activity of Rocha pear and other pear cultivars-a comparative study. Journal of Functional Foods, 2(2), 153-157. https://doi.org/10.1016/j.jff.2010.02.002

39. Ribas-Agustí, A., Martín-Belloso, O., Soliva-Fortuny, R., Elez-Martínez, P. (2018). Food processing strategies to enhance phenolic compounds bioaccessibility and bioavailability in plant-based foods. Critical Reviews in Food Science and Nutrition, 58(15), 2531-2548.

https://doi.org/10.1080/10408398.2017.1331200

40. Romero-González, J., Ah-Hen, K.S., Lemus-Mondaca, R., Muñoz-Fariña, O. (2020). Total phenolics, anthocyanin profile and antioxidant activity of maqui, Aristotelia chilensis (Mol.) Stuntz, berries extract in freeze-dried polysaccharides microcapsules. Food Chemistry, 313, art. no. 126115.

https://doi.org/10.1016/j.foodchem.2019.126115

41. Salehi, F. (2020). Physicochemical characteristics and rheological behaviour of some fruit juices and their concentrates. Journal of Food Measurement and Characterization, 14, 2472-2488. https://doi.org/10.1007/s11694-020-00495-0

42. Sanchez, C., Blanco, D., Oria, R., Sánchez-Gimeno, A.C. (2009). White guava fruit and purees: textural and rheological properties and effect of the temperature. Journal of Texture Studies, 40(3), 334-345.

https://doi.org/10.1111/j.1745-4603.2009.00185.x

43. Sandri, I.G., Silveira, M.M.d. (2018). Production and application of pectinases from Aspergillus niger obtained in solid state cultivation. Beverages, 4(3), art. no. 48.

https://doi.org/10.3390/beverages 4030048

44. Santana, M.L., Bispo, J.A.C., de Sena, A.R., Teshima, E., de Brito, A.R., Costa, F.S., Franco, M., de Assis, S.A. (2021). Clarification of tangerine juice using cellulases from Pseudoyma sp. Journal of Food Science and Technology-Mysore, 58(1), 44-51. https://doi.org/10.1007/s13197-020-04511-5

45. Saxena, D., Sabikhi, L., Chakraborty, S.K., Singh, D. (2014). Process optimization for enzyme aided clarification of watermelon juice. Journal of Food Science and Technology, 51(10), 2490-2498.

https://doi.org/10.1007/s13197-012-0720-1

46. Schieber, A., Keller, P., Carle, R. (2001). Determination of phenolic acids and flavonoids of apple and pear by high-performance liquid chromatography. Journal of Chromatography A, 910(2), 265-273.

https://doi.org/10.1016/S0021-9673(00)01217-6

47. Sethi, S., Joshi, A., Arora, B., Bhowmik, A., Sharma, R., Kumar, P. (2020). Significance of FRAP, DPPH, and CUPRAC assays for antioxidant activity determination in apple fruit extracts. European Food Research and Technology, 246(3), 591-598. https://doi.org/10.1007/s00217-020-03432-z

48. Shankar, S., Laxman, R.S. (2015). Biophysicochemical characterization of an alkaline protease from Beauveria sp. MTCC 5184 with multiple applications. Applied Biochemistry and Biotechnology, 175(1), 589-602.

https://doi.org/10.1007/s12010-014-1314-3

49. Sharma, H.P., Patel, H., Sugandha, (2017). Enzymatic added extraction and clarification of fruit juices - a review. Critical Reviews in Food Science and Nutrition, 57(6), 1215-1227.

https://doi.org/10.1080/10408398.2014.977434

50. Singh, V., Jawandha, S., Gill, P. (2021). Effect of exogenous putrescine treatment on internal browning and colour retention of pear fruit. Journal of Food Measurement and Characterization, 15, 905-913.

https://doi.org/10.1007/s11694-020-00696-7

51. Sorrivas, V., Genovese, D., Lozano, J. (2006). Effect of pectinolytic and amylolytic enzymes on apple juice turbidity. Journal of Food Processing and Preservation, 30(2), 118-133. https://doi.org/10.1111/j.1745-4549.2006.00054.x

52. Tavares, D.T., Alcantara, M.R., Tadini, C.C., Telis-Romero, J. (2007). Rheological properties of frozen concentrated orange juice (FCOJ) as a function of concentration and subzero temperatures. International Journal of Food Properties, 10(4), 829-839. https://doi.org/10.1080/10942910601118805

53. Thaochan, N., Ngampongsai, A., Prabhakar, C.S., Hu, Q. (2021). Beauveria bassiana PSUB01 simultaneously displays biocontrol activity against Lipaphis erysimi (Kalt.)(Hemiptera: Aphididae) and promotes plant growth in Chinese kale under hydroponic growing conditions. Biocontrol Science and Technology, 31(10), 997-1015.

https://doi.org/10.1080/09583157.2021.1917512 
54. Uçan, F., Ağçam, E., Akyildiz, A. (2016). Bioactive compounds and quality parameters of natural cloudy lemon juices. Journal of Food Science and Technology, 53(3), 1465-1474.

https://doi.org/10.1007/s13197-015-2155-y

55. Wang, J., Vanga, S.K., Raghavan, V. (2019). High-intensity ultrasound processing of kiwifruit juice: Effects on the ascorbic acid, total phenolics, flavonoids and antioxidant capacity. LWT - Food Science and Technology, 107, 299-307.

https://doi.org/10.1016/j.Iwt.2019.03.024

56. Xie, D., Zhong, H.-Y., Mo, J., Li, Z.-H., Cui, T., Yi, C.-P. (2007). Nutritional and medicinal quality of pear juice: Next hotspot? Food, 1(1), 41-48.
57. Yang, S.Q., Dai, X.Y., Wei, X.Y., Zhu, Q., Zhou, T. (2019). Co-immobilization of pectinase and glucoamylase onto sodium aliginate/graphene oxide composite beads and its application in the preparation of pumpkin-hawthorn juice. Journal of Food Biochemistry, 43(3), art. no. e12741.

https://doi.org/10.1111/jfbc.12741

58. Zhao, D., Wang, Y., Na, J., Ping, W., Ge, J. (2019). The response surface optimization of $\beta$-mannanase produced by Lactobacillus casei HDS-01 and its potential in juice clarification. Preparative Biochemistry and Biotechnology, 49(2), 202-207.

https://doi.org/10.1080/10826068.2019.1566151 
